Harvests, Feasts, And Graves 



\title{
Harvests, Feasts, AND GRAVES
}

\section{Postcultural Consciousness in Contemporary Papua New Guinea}

\author{
RYAN SCHRAM
}


Copyright $\odot 2018$ by Cornell University

All rights reserved. Except for brief quotations in a review, this book, or parts thereof, must not be reproduced in any form without permission in writing from the publisher. For information, address Cornell University Press, Sage House, 512 East State Street, Ithaca, New York 14850.

First published 2018 by Cornell University Press

Printed in the United States of America

Library of Congress Cataloging-in-Publication Data

Names: Schram, Ryan, author.

Title: Harvests, feasts, and graves : postcultural consciousness in contemporary Papua New Guinea / Ryan Schram.

Description: Ithaca : Cornell University Press, 2018. I Includes bibliographical references and index.

Identifiers: LCCN 2017027638 (print) | LCCN 2017033044 (ebook) | ISBN 9781501711022 (epub/mobi) | ISBN 9781501711015 (pdf) | ISBN 9781501710995 (cloth: alk. paper) I ISBN 9781501711008 (pbk.: alk. paper)

Subjects: LCSH: Ethnology_Papua New Guinea-Milne Bay Province. I Social change-Papua New Guinea-Milne Bay Province. | Postcolonialism-Papua New Guinea-Milne Bay Province. I Milne Bay Province (Papua New Guinea)-Social life and customs.

Classification: LCC GN671.N5 (ebook) I LCC GN671.N5 S36 2018 (print) I DDC 303.409953-dc23

LC record available at https://lccn.loc.gov/2017027638

Cornell University Press strives to use environmentally responsible suppliers and materials to the fullest extent possible in the publishing of its books. Such materials include vegetable-based, low-VOC inks and acid-free papers that are recycled, totally chlorine-free, or partly composed of nonwood fibers. For further information, visit our website at cornellpress.cornell.edu.

Cover photo by Ryan Schram, 2006 
Teina bu'i yagu waligehao vehabadi. Ryan Alexander, Ryan Jack David, yagu velau alimiyai. Yauwedo.

(This book is for my namesakes.

Ryan Alexander, Ryan Jack David, my love to you. Thank you.) 
